\title{
PERAN MKWU BAHASA INDONESIA SEBAGAI PENGUAT IDENTITAS DAN NASIONALISME MAHASISWA PTKI (STUDI PELAKSANAAN MKWU BAHASA INDONESIA DI UIN SYARIF HIDAYATULLAH JAKARTA)
}

\section{Nuryani*, Ahmad Bahtiar}

Pendidikan Bahasa Indonesia, UIN Syarif Hidayatullah Jakarta, Jl. Ir H. Juanda No.95, Cempaka. Putih, Kecamatan Ciputat, Kota Tangerang Selatan, Indonesia

*Corresponding author: nuryani@uinjkt.ac.id

\section{INFORMASI ARTIKEL}

Sejarah Artikel

Diterima: 4/5/2019

Direvisi: 9/12/2019

Diterima: $11 / 12 / 2019$

Tersedia Daring: 30/12/2019

Kata Kunci

MKWU Bahasa Indonesia

Identitas

Nasionalisme
Permasalah utama dalam penelitian ini adalah bagaimana peran MKWU Bahasa Indonesia dalam memperkuat identitas dan rasa nasionalisme mahasiswa. Tujuan penelitian ini adalah untuk mendeskripsikan peran Mata Kuliah Wajib Umum (MKWU) Bahasa Indonesia di UIN Syarif Hidayatullah Jakarta dalam memperkuat identitas dan rasa nasionalisme mahasiswa. Mata kuliah Bahasa Indonesia sebagai mata kuliah yang diajarkan di semua jurusan dan fakultas harus mampu mendukung dalam memperkuat identitas dan rasa nasionalisme mahasiswa. Dengan begitu mata kuliah ini tidak hanya diajarkan dalam rangka pemenuhan nilai semata. Metode penelitian ini adalah deskriptif kualitatif. Metode pengambilan data dilakukan melalui studi dokumen dan wawancara. Hasil penelitian ini adalah peran MKWU Bahasa Indonesia dalam memperkuat identitas dan rasa nasionalisme mahasiswa diwujudkan melalui tagihan-tagihan yang diberikan. Tagihan tersebut diharapkan dapat menstimulasi atau mendorong mahasiswa memiliki sikap dan pemikiran kritis terhadap permasalahan yang dihadapi oleh bangsanya. Selain itu, beberapa tagihan yang diberikan juga mengungkapkan identitas yang mengedepankan visi UIN Syarif Hidayatullah Jakarta, yakni keislaman, keindonesiaan, dan kekeilmuwan, salah satunya memiliki rasa cinta terhadap bangsa dan negara serta penghargaan yang tinggi terhadap bahasa Indonesia.

\section{Keywords \\ MKWU Indonesian \\ Identity \\ Nationalism}

\section{ABSTRACT}

The main problem in this research is how the role of the Indonesian Language Course is in strengthening the identity and sense of student nationalism. The purpose of this study is to describe the role of the Indonesian Language Course at UIN Syarif Hidayatullah Jakarta in strengthening the identity and sense of student nationalism. Indonesian Language courses as the subjects taught in all departments and faculties must be able to support in strengthening the identity and sense of students' nationalism. Therefore, this course is not only taught in the context of fulfilling grades alone. This research method is descriptive qualitative. The data collection method is carried out through document studies and interviews. The results of this study are the roles of the Indonesian Language course in strengthening the identity and sense of nationalism of students realized through the bills given. The bill is expected to stimulate or encourage students to have an attitude and critical thinking for the problems faced by their nation. Besides, several bills that are given have revealed identities that are put forward the vision of UIN Syarif Hidayatullah Jakarta, namely Islam, Indonesianism, and scholarship, one of which represents love for the nation and the state as well as high respect for the Indonesian language. 


\section{PENDAHULUAN}

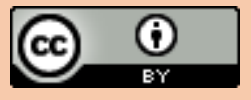

Universitas menjadi salah satu institusi penyelenggara pendidikan tinggi yang secara struktural bertanggung jawab kepada pemerintah. Indonesia memiliki banyak institusi lembaga penyelenggara pendidikan tinggi. Seperti yang telah diatur dalam Undang-Undang No. 12 tahun 2012 tentang Pendidikan Tinggi yang dinyatakan bahwa yang di maksud dengan Pendidikan Tinggi adalah jenjang pendidikan setalah pendidikan menengah yang mencakup berbagai program studi. Dalam UU tersebut, tidak terdapat pembedaan antara pendidikan tinggi yang diselenggarakan di bawah Kemenristek Dikti dan di bawah Kementerian Agama. Untuk itulah, dalam beberapa hal penyelenggaraan pendidikan tinggi di bawah dua kementerian tersebut dianggap sama meskipun pada beberapa hal pendidikan tinggi di bawah Kementerian Agama memiliki beberapa kekhasan.

Pengertian pendidikan tinggi seperti yang diamanatkan oleh undang-undang di atas membawa konsekuensi bagi penyelenggaraan pendidikan tinggi. Oleh karena itu, dibutuhkan penjabaran dalam bentuk mata kuliah yang mampu merepresentasikan amanat tersebut. Sebelum menjabarkan dalam bentuk mata kuliah maupun materi yang akan diajarkan hendaknya perlu dicermati juga mengenai asas dan fungsi penyelenggaraan pendidikan tinggi yakni kebenaran ilmiah, penalaran, kejujuran, keadilan, manfaat, kebajikan, tanggung jawab, kebhinekaan, dan keterjangkauan. Kebhinekaan menjadi salah satu asas dalam penyelenggaraan pendidikan tinggi. Hal ini dilakukan karena pendidikan tinggi yang diselenggarakan di Indonesia harus sesuai dengan kebudayaan Indonesia. Artinya, dalam proses penyelenggaraannya harus dengan semangat keindonesiaan yang terkenal dengan kebhinekaannya. Oleh karena itu, setiap unsur dalam pendidikan tinggi harus mampu membawa seluruh civitasnya memiliki nasionalisme tinggi guna menjaga keutuhan NKRI.

Kebhinekaan Indonesia salah satunya terwujud dalam hal kebahasaan. Jumlah itu mencapai lebih dari 500 bahasa (Simarmata, 2017). Untuk itulah, membicarakan kebudayaan Indonesia tidak sama dengan membicarakan budaya satu daerah tertentu. Dengan beragamnya kebudayaan, suku, agama, dan bahasa yang dimiliki maka Indonesia membutuhkan satu hal yang mampu menjadi perekat atau pemersatu di antara kebudayaan dan bahasa yang berbeda. Dengan adanya bahasa persatuan, yakni bahasa Indonesia, mampu menjadi alat pemersatu seluruh masyarakat Indonesia yang beragam latar belakang.

Sesuai dengan isi Sumpah Pemuda yang salah satunya berbunyi "menjunjung tinggi bahasa persatuan bahasa Indonesia". Dari salah satu isi sumpah pemuda tersebut dapat dikatakan bahwa bahasa Indonesia menjadi bahasa perekat atau pemersatu di antara suku-suku yang beragam. Oleh karenanya, wajib kiranya bagi seluruh masyarakat Indonesia menguasai bahasa Indonesia guna memperlancar proses komunikiasi antarbudaya. Dengan begitu, akan dapat meminimalkan kesalahpahaman yang ada dalam berbagai sisi kehidupan, salah satunya kesalahpahaman dalam bidang keagamaan. Terlebih melihat situasi dan kondisi akhir-akhir ini ketika Islam terkadang pada posisi terpojokkan, tidak ada pilihan lain kecuali mulai membangun generasi dan ilmuan Islam yang memiliki dedikasi tinggi, sikap kejujuran, dan memiliki rasa nasionalisme yang kuat.

Selain menjadi bahasa pemersatu bahasa Indonesia juga memiliki fungsi dan kedudukan yang strategis. Salah satu fungsi bahasa Indonesia adalah menjadi bahasa pengantar di lembaga pendidikan. Selain itu, bahasa Indonesia juga wajib digunakan dalam setiap kegiatan baik 
nasional maupun internasional yang diselenggarakan di Indonesia sesuai UU No. 24 Tahun 2009 tentang Bendera, bahasa, dan Lambang Negara, serta Lagu Kebangsaan. Mengingat begitu pentingnya posisi bahasa Indonesia dalam budaya Indonesia maka pemerintah mewajibkan bahasa Indonesia menjadi salah satu mata pelajaran dan mata kuliah di setiap lembaga pendidikan dan setiap jenjang pendidikan.

Terkait dengan penyelenggaraan mata kuliah Bahasa Indonesia di perguruan tinggi, pemerintah telah mengeluarkan surat edaran yang terkait dengan pelaksanaan mata kuliah wajib umum (MKWU). Surat edaran tersebut ditandatangani oleh Direktor Jenderal dan bernomor 435/B/SE/2016 (Risetdikti, 2017). Dalam surat edaran tersebut menegaskan bahwa "Amanat Undang-Undang Nomor 12 Tahun 2012 Pasal 35 Ayat 3 menyatakan bahwa kurikulum pendidikan tinggi wajib memuat mata kuliah Agama, Pancasila, Pendidikan Kewarganegaraan, dan Bahasa Indonesia untuk program sarjana dan diploma.” Berdasarkan amanat tersebut, kiranya wajib bagi setiap institusi pendidikan tinggi untuk memasukkan mata kuliah Bahasa Indonesia dalam satuan pengajarannya. Dalam pelaksanaannya, sesuai dengan pertemuan Konsorsium Mata Kuliah Wajib Umum (MKWU) yang dilaksanakan di Bandung pada bulan Mei 2017, ketiga MKWU di atas harus selalu terintegrasi. Ketiga MKWU tersebut tidak dapat dipisahkan satu dengan yang lain. Artinya, pembelajaran ketiga MKWU tersebut terintegrasi baik dalam bentuk materi, penugasan/tagihan, sampai pada praktik dalam kegiatan pembelajarannya (Kusnadi, 2016).

Kebijakan pemerintah terkait dengan pelaksanaan MKWU Bahasa Indonesia bahkan sudah ada sejak tahun 2006. Terlihat dalam Surat Putusan Direktorat Jenderal Pendidikan Tinggi, Departemen Pendidikan Nasional, Nomor 43/DIKTI/Kep/2006 tentang Pelaksanaan Kelompok Mata Kuliah Pengembangan Kepribadian (MPK) (Arifin \& Tasai, 2015). Dalam putusan tersebut dijelaskan bahwa melalui pelaksanaan mata kuliah Bahasa Indonesia diharapkan akan dapat mengembangkan kepribadian mahasiswa melalui pengembangan bahasanya. Dijelaskan oleh Widjono Hs, bahwa pengalaman berbahasa yang amat berharga dalam pengembangan kepribadian bangsa Indonesia kemudian dikukuhkan dalam kedudukannya dalam Undang-Undang Dasar 1945 yang menyatakan bahwa bahasa negara adalah Bahasa Indonesia (Widjono, 2012).

Selain melalui surat edaran, kebijakan pemerintah tertinggi yang diamanatkan dalam Undang-Undang Nomor 12 Tahun 2012 Pasal 35 ayat 3 tentang Kurikulum Pendidikan Tinggi, memuat mata kuliah wajib yakni Agama, Pancasila, Kewarganegaraan, dan Bahasa Indonesia. Kementerian Riset, Teknologi, dan Pendidikan Tinggi juga mengeluarkan Bahan ajar mata kuliah wajib umum Mata kuliah Bahasa Indonesia. Bahan ajar yang berupa buku tersebut berjudul "Buku Ajar Mata Kuliah Wajib Umum Bahasa Indonesia: Ekspresi Diri dan Akademik" (Direktorat Jenderal Pembelajaran dan Kemahasiswaan, 2016). Dalam Sambutannya selaku Direktur Pembelajaran, Paristiyanti Nurwardani menyampaikan bahwa dalam upaya meningkatkan mutu lulusan dan pembentukan karakter bangsa perlu dilakukan peningkatan dan perbaikan materi yang dinamis mengikuti perkembangan yang senantiasa dilakukan secara terus menerus, dan dimutakhirkan sesuai dengan dinamika kebutuhan dan perubahan zaman serta semangat bela negara (Direktorat Jenderal Pembelajaran dan Kemahasiswaan, 2016). Dengan demikian, kehadiran buku ajar ini diharapkan mahasiswa dapat memiliki rasa nasionalisme dan dapat mencintai bahasa serta negaranya.

Bahasa Indonesia menjadi salah satu Mata Kuliah Wajib Umum (MKWU) yang harus ada di setiap perguruan tinggi, tidak terkecuali di Perguruan Tinggi Keagamaan Islam (PTKI). Demikian juga dengan di Universitas Islam Negeri (UIN) Syarif Hidayatullah Jakarta. Di UIN Jakarta Bahasa Indonesia menjadi mata kuliah wajib di semua fakultas. Harapan yang sama juga diemban dalam pelaksanaan mata kuliah Bahasa Indonesia di UIN Jakarta. Mata kuliah ini diberikan selain untuk membekali mahasiswa mampu memiliki pengetahuan tentang bahasa 
Indonesia secara umum juga untuk membangun rasa cinta mahasiswa terhadap bahasa dan bangsanya. Untuk itulah dalam tulisan ini akan melihat peran MKWU Bahasa Indonesia sebagai penguat rasa nasionalisme mahasiswa di PTKI (Studi pada Pelaksanaan MKWU Bahasa Indonesia di UIN Syarif Hidayatullah Jakarta).

Terkait dengan materi pembelajaran Bahasa Indonesia sebagai MKWU di UIN Syarif Hidayatullah Jakarta telah dilakukan oleh beberapa penelitian oleh dosen-dosen pengampu. Beberapa dosen yang pernah melakukan penelitian adalah (Mulyana, 2018; Nuryani, 2014a; Putra, 2015). Penelitian yang dilakukan oleh Mulyana terkait dengan pengetahuan mahasiswa mengenai ejaan. Demikian juga dengan penelitian yang dilakukan oleh Nuryani juga terkait dengan kesalahan-kesalahan ejaan yang dilakukan oleh mahasiswa Non-PBSI. Penelitian ini dilakukan pada tahun 2014 sehingga masih menggunakan pedoman Ejaan yang Disempurnakan (EYD). Sementara itu, penelitian yang dilakukan oleh Putra terkait dengan kemampuan membaca kritis oleh mahasiswa di Fakultas Syariah dan Hukum. Beberapa penelitian yang telah dilakukan tersebut belum ada yang meneliti mengenai peran mata kuliah Bahasa Indonesia dalam memperkuat identitas dan rasa nasionalisme mahasiswa. Untuk itulah penelitian ini dilakukan guna mendapatkan gambaran mengenai peran mata kuliah Bahasa Indonesia.

\section{METODE}

Penelitian ini merupakan jenis penelitian deskriptif kualitatif. Jenis penelitian tersebut adalah penelitian yang menyajikan fakta secara apa adanya. Data yang dianalisis dalam penelitian ini berupa materi-materi yang terdapat dalam silabus dan buku rujukan serta bentuk tugas atau tagihan akhir dalam pembelajaran MKWU Bahasa Indonesia. Sumber data penelitian ini adalah silabus dan buku yang digunakan untuk mengajar MKWU Bahasa Indonesia serta kegiatan pembelajarannya. Teknik pengumpulan data dilakukan melalui teknik dokumentasi atau kepustakaan dan wawancara. Kepustakaan meliputi silabus dan buku rujukan. Sementara itu, wawancara dilakukan dengan beberapa dosen pengampu mata kuliah bahasa Indonesia. Wawancara dilakukan guna mengetahui implementasi silabus dalam pembelajaran. Hal tersebut penting karena jenis tugas, penyusunan soal-soal, pemilihan tema penulisan, sampai pada praktik pembelajaran harian akan mempengaruhi hasil akhir dan peran MKWU Bahasa Indonesia itu sendiri. Karena penelitian ini merupakan penelitian kualitatif maka peneliti sendiri yang bertindak sebagai instrumen dalam penelitian. Penyajian data dilakukan secara formal dan informal, yakni dengan penyajian berupa tabel dan deskripsi melalui kata-kata.

\section{HASIL PENELITIAN DAN PEMBAHASAN \\ Hasil}

Hasil penelitian yang disajikan meliputi bagian-bagian silabus MKWU Bahasa Indonesia dan beberapa bentuk tugas atau tagihan mahasiswa.

\section{Beberapa Bagian dalam Silabus}

\section{Mata Kuliah Bahasa Indonesia}

\section{Standar Kompetensi}

Mahasiswa memiliki kemahiran berbahasa Indonesia dalam bentuk tulisan dan lisan dengan baik dan benar.

Kemampuan Akhir yang direncanakan :

1. Mahasiswa mampu berbicara dalam presentasi ilmiah; 
2. Mahasiswa mampu menjelaskan perkembangan bahasa Indoensia;

3. Mahasiswa mampu memahami pemakaian huruf dan kata;

4. Mahasiswa mampu memahami unsur serapan dan tanda baca;

5. Mahasiswa mampu menggunakan transliterasi dengan tepat;

6. Mahasiswa mampu menggunakan diksi dengan benar;

7. Mahasiswa mampu membuat kalimat efektif;

8. Mahasiswa mampu membuat paragraf dengan benar;

9. Mahasiswa mampu memahami plagiasi;

10. Mahasiswa mampu membuat perencanaan karangan;

11. Mahasiswa mampu melakukan penalaran dengan tepat;

12. Mahasiswa mampu menggunakan notasi ilmiah dengan cepat;

13. Mahasiswa mampu memperoduksi tulisan pendek dengan baik dan benar;

14. Mahasiswa mampu menghasilkan reproduksi tulisan dengan benar;

\section{Deskripsi Mata Kuliah}

Mata kuliah ini bertujuan mememahirkan mahasiswa dalam menulis karya ilmiah seperti makalah dan laporan serta skripsi dengan standar penulisan karya ilmiah yang baik dan benar. Materi yang disajikan berkisar pada konsep-konsep berpikir kritis dan konvensi penulisan ilmiah. Di samping itu, juga tentang plagiarisme dan apresiasi terhadap buah pemikiran dan karya akademik.

\section{Indikator}

1. Menjunjung tinggi nilai-nilai akademik, yang meliputi kejujuran dan kebebasan akademik dan otonomi akademik

2. Mampu memberikan presentasi yang jelas, padat, dan berkualitas baik dalam bentuk tulisan maupun lisan

3. Mampu melakukan argumentasi ilmiah atas presentasi data yang diberikan

4. Menunjukkan kemampuan menulis karya ilmiah yang baik dan benar sesuai dengan kaidah yang berlaku

\section{Bahan Kajian :}

(Materi Pokok Perkuliahan)

1. Berbicara dalam presentasi ilmiah;

2. Perkembangan Bahasa Indonesia;

3. Pemakaian dan penggunaan huruf dan kata;

4. Unsur serapan, tanda baca, dan transliterasi;

5. Diksi/Pilihan Kata;

6. Kalimat Efektif;

7. Paragraf;

8. Etika Ilmiah/Plagiasi;

9. Perencanaan Karangan;

10. Penalaran;

11. Notasi Ilmiah;

12. Produksi Tulisan Pendek;

13. Reproduksi Tulisan;

14.

\section{Pengalaman Belajar:}

(mahasiswa yang diwujudkan dalam deskripsi tugas yang harus dikerjakan oleh mahasiswa selama satu semester) 
1. Membuat makalah presentasi;

2. Membuat berbagai tulisan ilmiah;

3. Membuat analisis kesalahan bahasa dalam tataran tulis (skripsi, jurnal, dll.);

4. Membuat reproduksi tulisan;

5. Praktik berpidato dan presentasi ilmiah.

\section{Tugas/Tagihan Mahasiswa}

\begin{tabular}{lll}
\hline No & Jurusan & Bentuk Tagihan Akhir \\
\hline 1 & Pend. Bahasa & $\begin{array}{l}\text { Membuat semacam kamus yang memuat } \\
\text { perbandingan kosa kata bahasa Indonesia } \\
\text { yang diserap dari bahasa Arab }\end{array}$ \\
\hline 2 & $\begin{array}{l}\text { Hukum } \\
\text { Keluarga }\end{array}$ & $\begin{array}{l}\text { Membuat tulisan berupa esai dengan tema } \\
\text { "Menata Keluarga Indonesia dalam } \\
\text { Perspektif Islam" }\end{array}$ \\
\hline 3 & PBSI & $\begin{array}{l}\text { Membuat resume buku "Khazana Bahasa } \\
\text { Indonesia" }\end{array}$ \\
\hline 4 & Kesmas & $\begin{array}{l}\text { Membuat resensi film WAGE, yaitu salah } \\
\text { satu film tentang tokoh/pahlawan nasional }\end{array}$ \\
\hline
\end{tabular}

\section{Pembahasan}

\section{Integritas Keilmuwan sebagai Identias UIN}

Nata (2017) menyampaikan bahwa idealnya, pendidikan Islam saat ini, baik secara teoretis-konseptual maupun empiri-praktikal, lebih unggul dibanding pendidikan Islam sebelumnya maupun pendidikan lainnya. Hal tersebut didasarkan pada sejumlah alasan. Pertama, bahwa kitab suci Al-Quran dan Al-Hadist yang merupakan sumber utama ajaran Islam memberikan perhatian yang besar terhadap pendidikan. Kedua, keadaan umat Islam saat ini secara sosial maupun ekonomi jauh lebih banyak dibandingkan dengan umat Islam di masa lalu. Ketiga, secara historis umat Islam memiliki modal sejarah dan contoh yang sangat berharga bagi kemajuan pendidikannya. Melihat sejumlah alasan yang dikemukakan di atas maka sudah selayaknya perguruan tinggi Islam menjadi pionir dalam kemajuam di bidang pendidikan (Walid, 2011). Kenyataan pada saat ini sudah menunjukkan ke arah kemajuan tersebut. Sejumlah perguruan tinggi Islam sudah mampu menunjukkan kepada dunia bahwa pendidikan tinggi Islam sangat bisa berkompetisi dengan perguruan yang lain. Salah satu cara yang dapat ditempuh adalah dengan memposisikan diri untuk menjadi yang terbaik dan memiliki kekhasan sebagai perguruan tinggi Islam (Ikhwan, 2016).

Nilai keislaman dapat menjadi salah satu kekhasan perguruan tinggi Islam dibandingkan perguruan tinggi yang lain. Selain keislaman saja, nilai-nilai keindonesian yang terintegrasi dengan nilai keisalaman juga menjadi kekhasan perguruan tinggi Islam. Untuk itulah, UIN Syarif Hidayatullah memiliki motto yang dapat menggambarkan kekhasan tersebut. Adapun motto UIN Syarif Hidayatullah Jakarta adalah Keislaman, Keindonesian, dan Keilmuan. Berdasarkan motto ini jelas ingin memperlihatkan posisi UIN Syarif Hidayatullah Jakarta di antara perguruan tingi yang lain. Dengan tetap mengedepankan keislaman sebagai kekhasan, tetap menjaga keindonesiaan sebagai negara kesatuan yang menaunginya, dan mengedepankan keilmuan sebagai sebuah perguruan tinggi yang mencetak generasi ilmuan.

Dalam posisinya sebagai salah satu perguruan tinggi yang berada di Indonesia, UIN Syarif Hidayatullah tetap tunduk pada perundangan pendidikan yang berlaku. Undang-undang pendidikan mengamanatkan bahwa beberapa mata kuliah disusun secara mandiri oleh perguruan tinggi dan beberapa mata kuliah telah diwajibkan oleh negara. Hal tersebut tentunya 
berimbas pada mata kuliah yang dibebankan kepada mahasiswa sarjana menjadi cukup banyak dan dirasa cukup berat. Terlebih untuk mahasiswa yang berada di bawah perguruan tinggi keislaman. Beratnya beban kurikulum terutama bersumber dari banyaknya mata kuliah yang bukan substantif keilmuan (Nata, 2017). Dalam sebuah PTKI, terdapat mata kuliah keuniversitasan, kefakultasan, keislaman, keprodian, dan mata kuliah wajib. Kehadiran mata kuliah-mata kuliah tersebut tidak lantas menggugurkan salah satu mata kuliah wajib yang harus diberikan kepada mahasiswa. Salah satunya adalah mata kuliah wajib umum Bahasa Indonesia. Mata kuliah ini memiliki peran yang sangat strategis dalam pelaksanaannya. Setiap tugas mahasiswa disusun dengan menggunakan bahasa Indonesia dan mengikuti kaidah bahasa Indonesia. Selain itu, tugas akhir mahasiswa juga disusun dalam bahasa Indonesia. Untuk itulah, pelaksanaan MKWU Bahasa Indonesia harus mampu menjembatani hal-hal tersebut. Oleh karenanya, materi-materi yang disajikan dalam MKWU Bahasa Indonesia harus mengintegrasikan teori kaidah dengan praktik menulis dalam bahasa Indonesia yang benar (Kuntarto, 2016).

Rahardi (2010) menyampaikan dalam prakata bukunya, memang harus diakui bahwa belajar bahasa Indonesia untuk keperluan lisan maupun tulis tidak selalu mudah dilakukan. Sekalipun mahasiswa sudah lama mendapatkan materi Bahasa Indonesia, bahkan sejak mereka beada di bangku sekolah terendah sudah mendapatkannya, tetapu hingga saat kuliah di perguruan tinggi, penguasaan berbahasa Indonesia mereka banyak yang masih sangat memprihatinkan (Rahardi, 2010). Demikain juga dengan penguasaan bahasa Indonesia dalam tataran menulis ilmiah. Berdasarkan penelitian yang dilakukan oleh Nuryani terkait dengan penguasaan Ejaan yang Disempurnakan (EYD) oleh mahasiswa non-PBSI, dinyatakan bahwa masih terdapat banyak kesalahan yang ditemukan dalam tulisan mahasiswa. Kesalahan ejaan yang ditemukan di antaranya adalah pada penulisan huruf kapital, penggunaan huruf miring, penggunaan imbuhan, penggunaan tanda titik, pengguna tanda koma, dan penggunaan tanda titik koma (Nuryani, 2014b). Berdasarkan hasil penelitian tersebut dapat disampaikan bahwa memang tidak mudah untuk menguasai bahasa Indonesia yang benar sesuai kadiah dalam kegiatan menulis ilmiah. Oleh karena itu, mata kuliah ini penting untuk tetap diberikan sekalipun kepada mahasiswa.

Bahasa Indonesia dijadikan mata kuliah pengembangan kepribadian di setiap perguruan tinggi, baik negeri maupun swasta, dengan tujuan agar para mahasiswa menjadi ilmuan atau menjadi profesional yang memiliki sikap bahasa yang positif terhadap bahasa Indonesia (Arifin \& Tasai, 2015). Gavin dan Mathiot menyampaikan, sikap positif terhadap bahasa Indonesia dicirikan dengan memiliki sikap setia dalam menggunakan bahasa Indonesia, memiliki kebanggaan terhadap bahasa Indonesia, serta memiliki kesadaran akan norma-norma atau kaidah yang ada dalam bahasa Indonesia (Nuryani, 2014a). Ciri yang pertama dan ketiga itulah yang dicoba untuk ditumbuhkembangan dalam kegiatan pembelajaran Bahasa Indonesia di perguruan tinggi.

Ciri pertama terkait dengan penggunaan bahasa Indonesia dalam setiap kegiatan mahasiswa baik secara lisan maupun tertulis. Hal tersebut sudah berlaku karena hampir setiap saat mahasiswa berkomunikasi dengan menggunakan bahasa Indonesia. Dalam ragam tulis, tugas dan tagihan hampir semua mata kuliah disusun menggunakan bahasa Indonesia (kecuali untuk mata kuliah Bahasa Inggris dan Bahasa Arab). Sementara itu, ciri yang ketiga terkait dengan penguasaan norma-norma kebahasaan, dalam mata kuliah Bahasa Indonesia dicoba untuk disampaikan. Hal tersebut dapat terlihat dari materi-materi yang disusun dalam Rencana Perkuliahan Semester (RPS) dan Silabus Mata Kuliah Bahasa Indonesia.

Dalam Standar kompetensi, mata kuliah Bahasa Indonesia adalah mahasiswa memiliki kemahiran berbahasa Indonesia dalam bentuk tulisan dan lisan dengan baik dan benar. Standar kompetensi ini membawa banyak implikasi, salah satunya mahasiswa harus menguasai bahasa 
Indonesia dengan baik sesuai dengan konteks ketika bahasa tersebut digunakan dan harus berbahasa secara benar sesuai dengan kaidah bahasa Indonesia (Kusnadi, 2016). Melalui pembelajaran, penguasaan bahasa Indonesia diharapkan dapat mengembangkan berbagai kecerdasan, karakter, dan kepribadian. Orang yangmenguasai bahasa Indonesia secara aktif dan pasif akan dapat mengekspresikan pemahaman dan kemampuan dirinya secara runtut, sistematis, logis, dan lugas. Hal ini dapat menandai kemampuan mengorganisasi karakter dirinya yang terkait dengan potensi daya pikir, emosi, keinginan, dan harapan yang kemudian diekspresikannya dalam berbagai bentuk: artikel, proposal proyek, penulisan laporan, lamaran pekerjaan, dan sebagainya (Widjono, 2012).

Pembelajaran mata kuliah Bahasa Indonesia di perguruan tinggi memiliki beberapa tujuan. Zaenal Arifin dan Amran Tasai membaginya menjadi tujuan umum dan tujuan khusus. Tujuan umum seperti telah disebutkan di atas, yakni untuk membentuk mahasiswa menjadi ilmuan yang memiliki sikap bahasa yang positif terhadap bahasa Indonesia. Sementara itu, untuk tujuan khusus dibagi kembali menjadi dua, yakni tujuan jangka panjang dan tujuang jangka pendek (Tasai \& Arifin, 2010). Tujuan jangka pendek dan bersifat mendesak untuk keperluan mahasiswa pada akhir mata kuliah Bahasa Indonesia adalah agar mahasiswa mampu menyusun sebuah karya ilmiah dengan menggunakan bahasa Indonesia yang baik dan benar, dan agar mahasiswa dapat melakukan tugas-tugas (karangan ilmiah sederhana) dari dosendosen lain dengan menerapkan dasar-dasar yang diperoleh dari kuliah Bahasa Indonesia. Sementara itu, untuk tujuan jangka panjang agar mahasiswa sanggup menyusun skripsi sebagai persyaratan mengikuti ujian sarjana. Demikian juga, setelah lulus mahasiswa terampil menyusun kertas kerja, laporan penelitian, dan karya ilmiah yang lain.

Terkait dengan pelaksanaan MKWU Bahasa Indonesia di Universitas Islam Negeri (UIN) Syarif Hidayatullah Jakarta, universitas membentuk tim konsorsium MKWU Bahasa Indonesia. Tim ini dibentuk dan bertanggung jawab kepada Wakil Rektor I Bidang Akademik. Tim konsorsium memiliki tugas menyusun Satuan Acara Perkuliahan (SAP) dan Silabus Bahasa Indonesia. Satuan Acara Perkuliahan (SAP) dan Silabus ini yang digunakan oleh seluruh dosen pengampu mata kuliah Bahasa Indonesia di semua jurusan dan fakultas yang ada di UIN Syarif Hidayatullah Jakarta. Dengan begitu, tujuannya adalah untuk menyeragamkan materi dan jenis tugas atau tagihan yang diminta kepada mahasiswa. Selain itu, dengan penyeragaman ini akan dapat dipantau sejauh mana mata kuliah ini memberikan kontribusi bagi mata kuliah lain maupun jurusan dan fakultas setempat.

Beberapa materi yang disajikan dalam silabus MKWU Bahasa Indonesia di UIN Syarif Hidayatullah Jakarta memiliki perbedaan dengan silabus yang digunakan untuk perguruan tinggi umum. Hal tersebut dapat dilihat dari komposisi materi maupun uraian kegiatan pembelajarannya. Perbedaan tersebut guna memberikan kekhasan terhadap pengajaran Bahasa Indonesia di UIN Syarif Hidayatullah Jakarta. Oleh karena itu, dalam bagian ini akan disajikan Silabus mata kuliah Bahasa Indonesia yang digunakan di UIN Syarif Hidayatullah Jakarta dan materi-materi yang digunakan di perguruan tinggi lain yang diambilkan dari beberapa buku sumber.

Di atas adalah beberapa bagian yang terdapat dalam silabus yang digunakan di semua jurusan atau program studi di semua fakultas yang ada di UIN Syarif Hidayatullah Jakarta. Mata kuliah Bahasa Indonesia disampaikan dalam 16 kali pertemuan sudah termasuk Ujian Tengah Semester (UTS) dan Ujian Akhir Semester (UAS). Termasuk di dalamnya mencakup tugas-tugas dan tagihan yang diberikan kepada mahasiswa. Mengingat UIN Syarif Hidayatullah Jakarta adalah Universitas Islam dengan jumlah fakultas dan program studi (prodi) yang cukup banyak maka pelaksanaan MKWU Bahasa Indonesia juga diusahakan untuk menyesuaikan kondisi atau konteks prodi atau fakultas tempat MKWU tersebut diajarkan. Hal tersebut dilakukan dengan pertimbangan bahwa setiap prodi dan fakultas 
memiliki kekhasan tersendiri. Sebagai contoh adalah Fakultas Ilmu Tarbiyah dan Keguruan (FITK). Fakultas ini memiliki kekhasan yakni setiap mahasiswanya dididik untuk menjadi calon guru, sehingga beberapa tagihan menyesuaikan dengan profil keguruan. Di FITK biasanya mahasiswa diminta membuat karya ilmiah yang terkait dengan profil kependidikan, keguruan, sampai pada sistem pengajaran ataupun kebijakan pendidikan. Hal ini dilakukan supaya mahasiswa terbiasa dengan bahan bacaan atau materi terkait dengan kependidikan dan keguruan.

Tagihan yang berbeda diterapkan kepada mahasiswa di Fakultas Syariah. Fakultas Syariah memiliki beberapa prodi yang juga memiliki kekhasan. Sebagai contoh ketika mengajar MKWU di jurusan Hukum, maka tagihan yang diharapkan adalah mahasiswa menyusun karya ilmiah sederhana yang terkait dengan konteks hukun atau kebijakan-kebijakan hukum baik Hukum Keluarga, Hukum Islam, maupun Hukum Ekonomi Syariah, bergantung pada jurusan masing-masing. Demikian juga jika mengajarkan di Fakultas Kedokteran, Fakultas Psikologi, dan fakultas yang lain. Meskipun demikian, sesuai dengan amanat undangundang bahwa pelaksanaan MKWU harus terintegrasi maka dalam pelaksanaannya selain mempertimbangkan kekhasan jurusan/prodi dan fakultas, juga tetap mengintegrasikan dengan nilai-nilai Pancasila dan Agama. Hal ini sangat penting supaya nilai-nilai yang terkandung dalam ketiga MKWU tersebut bisa dipahami dan dipraktikkan secara baik dalam kehidupan berbangsa dan bernegara.

Perbedaan hanya berlaku pada tataran tagihan atau tugas yang diberikan. Sementara itu, untuk materi yang diberikan kepada semua mahasiswa di semua fakultas adalah sama, yakni mengacu pada silabus yang telah dibuat oleh tim konsorsium. Dengan kesamaan materi tersebut diharapkan semua mahasiswa di UIN Syarif Hidayatullah Jakarta akan memiliki pemahaman dan persepsi yang sama mengenai MKWU Bahasa Indonesia. Dengan demikian, tujuan pelaksanaan MKWU Bahasa Indonesia akan dapat tercapai.

Materi yang diajarkan di UIN Syarif Hidayatullah Jakarta secara umum mengacu pada materi yang disampaikan oleh pemerintah. Buku ajar yang disusun oleh Kemenristek Dikti (2016) memuat materi-materi sebagai berikut:

1. Pendahuluan, meliputi:

a. Kedudukan dan Fungsi Bahasa Indonesia

b. Bahasa Indonesia Baku

c. Kerangka Konseptual, Visi, dan Tujuan

d. Kompetensi dan Desain Pembelajaran

e. Pembelajaran Berbasis Teks

2. Mengeksplorasi Teks Akademik dalam Genre Makro

3. Menjelajah Dunia Pustaka

4. Mendesain Proposal Penelitian dan Proposal Kegiatan

5. Melaporkan Hasil Penelitian dan Hasil Kegiatan

6. Mengaktualisasi Diri Melalui Artikel Ilmiah.

Materi-materi di atas kemudian dikembangkan oleh tim konsorsium UIN Syarif Hidayatullah Jakarta. Tim konsorsium pada akhirnya mengurai materi-materi tersebut menjadi sebagai berikut.

1. Berbicara dalam presentasi ilmiah;

2. Perkembangan Bahasa Indonesia;

3. Pemakaian dan penggunaan huruf dan kata;

4. Unsur serapan, tanda baca, dan transliterasi;

5. Diksi/Pilihan Kata;

6. Kalimat Efektif; 
7. Paragraf;

8. Etika Ilmiah/Plagiasi;

9. Perencanaan Karangan;

10. Penalaran;

11. Notasi Ilmiah;

12. Produksi Tulisan Pendek;

13. Reproduksi Tulisan;

Sementara itu, berdasarkan sumber lain, yakni dalam bukunya (Arifin \& Tasai, 2015), menyebutkan beberapa materi kuliah Bahasa Indonesia. Materi-materi tersebut adalah sebagai berikut:

1. Pengantar kuliah

2. Perkembangan Bahasa Indonesia

3. Bahasa Indonesia dengan Berbagai Ragamnya

4. Diksi atau Pilihan Kata

5. Tata Kalimat

6. Paragraf atau Alinea

7. Penalaran Deduktif dan Induktif serta Salah Nalar

8. Tata Ejaan

9. Presentasi, Pidato, Seminar, Ringkasan, dan Resensi

10. Teknik Penulisan Karya Ilmiah.

Berdasarkan paparan materi dari berbagai sumber di atas dapat dilihat adanya beberapa perbedaan yang disajikan di MKWU Bahasa Indonesia di UIN Syarif Hidayatullah Jakarta. Perbedaan tersebut menjadi kekhasan tersendiri untuk materi MK Bahasa Indonesia di UIN Syarif Hidayatullah Jakarta khususnya dan di PTKI pada umumnya. Salah satu materi yang terlihat sangat berbeda adalah adanya materi Transliterasi. Materi ini tidak ditemukan di beberapa buku sumber yang lain. Materi tersebut juga tidak ditemukan di perguruan tinggi lain yang bersifat umum. Dengan demikian, materi ini menjadi kekhasan yang dimiliki oleh MKWU Bahasa Indonesia di UIN Syarif Hidayatullah Jakarta.

Salah satu bukti bahwa materi tersebut menjadi kekhasan MKWU di UIN Syarif Hidayatullah Jakarta adalah bahwa berdasarkan penelusuran pustaka terhadap beberapa buku bahan ajar yang lain tidak ditemukan materi tersebut. Beberapa buku yang dapat dilihat adalah Bahasa Indonesia: Mata Kuliah Pengembangan Kepribadian di Perguruan Tinggi (Widjono, 2012). Bahasa Indonesia untuk Perguruan Tinggi (Rahardi, 2010) dan Bahasa Indonesia sebagai Mata Kuliah Pengembangan Kepribadian (Arifin \& Tasai, 2015). Sementara itu, materi mengenai Transliterasi dapat dijumpai dalam buku Bahasa Indonesia yang disusun oleh dosen dari UIN Syarif Hidayatullah Jakarta sendiri. Buku-buku tersebut antara lain buku Bahasa Indonesia untuk Perguruan Tinggi (Bahtiar \& Fatimah, 2014) dan Disiplin Berbahasa Indonesia (Gani \& Fitriyah, 2010). Pada beberapa buku teks untuk PT umum materi tersebut tidak dijumpai. Dengan demikian, dapat disampaikan bahwa materi tersebut menjadi kekhasan MKWU Bahasa Indonesia UIN Syarif Hidayatullah Jakarta.

\section{Pembelajaran Bahasa Indonesia sebagai Penguat Rasa Nasionalisme}

Terdapat tiga belas (13) materi yang diajarkan dalam mata kuliah Bahasa Indonesia. Akan tetapi, secara garis besar mata kuliah tersebut terbagi atas 5 tema besar. Kelima tema besar tersebut adalah keterampilan berbicara formal, Perkembangan Bahasa Indonesia, ejaan, Karangan,dan produksi tulisan. Dalam tema keterampilan berbicara formal, terdapat materi Berbicara dalam Presentasi Ilmiah. Materi ini sarat dengan tantangan. Hal tersebut dikarenakan MKWU Bahasa Indonesia rata-rata disampaikan di semester awal (antara 1 atau 3). Mengingat 
masih semester awal, kemampaun dan pengalaman mahasiswa dalam berkomunikasi formal masih sangat terbatas. Berdasarkan wawancara yang dilakukan dengan beberapa dosen pengampu MKWU Bahasa Indonesia di beberapa fakultas ditemukan kenyataan mengenai keterampilan berbicara mahasiswa. Banyak mahasiswa yang sudah gugup dan tidak bernai bicara jika tidak betul-betul dipaksa. Dengan mata kuliah ini, mahasiswa diajarkan untuk berbicara di depan kelas dengan pendengar dari teman-teman sendiri. Topik yang disampaikan diminta yang terkait dengan kebangsaan, kebahasaan, dan rasa nasionalisme serta yang terkait dengan keislaman. Tidak mudah memang meminta mahasiswa untuk berbicara secara formal karena mahasiswa cenderung terlatih menggunakan bahasa lisan yang tidak formal. Akan tetapi, dengan materi ini akan dapat menumbuhkan sikap berani tampil dan berbicara dengan bahasa formal sekaligus mampu membaca arah pemikiran mereka terkait dengan permasalahan atau tema yang disajikan.

Selain keterampilan berbicara mahasiswa juga dituntut untuk memiliki keterampilan membaca. Salah satu yang harus dikuasai adalah kemampuan/keterampilan membaca kritis. Terkait dengan keterampilan ini, Putra telah melakukan penelitian yang dilakukan terhadap mahasiswa Jurusan Perbankan Syariah Fakultas Syariah dan Hukum. Menurut Putra mahasiswa perlu terus diinspirasi, dimotivasi, dan difasilitasi agar tekun dan giat membaca (Putra, 2015). Penelitian yang dilakukan oleh Putra bertujuan untuk mendeskripsikan tingkat keterampilan membaca kritis pada mahasiswa Jurusan Perbankan Syariah semester IV pada tahun 2012/2013. Simpulan yang didapatkan dalam penelitian ini adalah bahwa mahasiswa sudah cukup terampil dalam membaca kritis terhadap suatu teks. Hal tersebut terlihat dari angka yang diperoleh yakni berada di angka 77,35.

Materi kedua adalah terkait dengan Perkembangan Bahasa Indonesia. Materi ini biasanya sangat menarik karena akan membicarakan sejarah awal mula bahasa Indonesia sampai akhrinya mampu menjadi bahasa pemersatu di Indonesia. Keberhasilan bahasa Indonesia dalam memenuhi peran dan menjalankan fungsinya sebagai bahasa persatuan dan bahasa negara itu sangat erat berkaitan dengan dua hal, yakni masalah teknis dan masalah prinsip. Masalah teknis berhubungan dengan hal kebahasaan, sedangkan masalah prinsip dengan hal sikap keindonesiaan (Alwi, 2011). Masalah-masalah tersebut sering dijadikan bahan diskusi oleh mahasiswa dan dosen yang pada akhirnya mengerucut pada satu simpulan, bahwa harus kembali kepada Sumpah Pemuda. Meskipun sebelum pelaksanaan mata kuliah Bahasa Indonesia, banyak atau bahkan hampir semua mahasiswa tidak hafal dengan isi sumpah pemuda, namun pada akhirnya setelah berdiskusi dan mengetahui tentang perjuangan dalam sumpah pemuda mahasiswa dapat lebih menghargai bahasa sendiri. Peristiwa Sumpah Pemuda 1928 sekurang-kurangnya didahului oleh dua peristiwa penting sebelumnya, yaitu kelahiran Budi Utomo pada tanggal 20 Mei 1908 yang menandai hari kebangkitan nasional dan berdirinya Balai Pustaka pada tanggal 22 September 1917 yang boleh disebut sebagai langkah awal pencerdasan kehidupan bangsa lewat bacaan (Alwi, 2011). Dengan manghadirkan sejarah dan lika liku perjuangan untuk mendapatkan bahasa pemersatu, mahasiswa akan dapat lebih menghargai dan kemudian tumbuh rasa nasionalisme dalam diri mereka.

Tema materi ketiga adalah Ejaan. Ejaan mencakup pemakaian huruf dan kata, unsur serapan, tanda baca, transliterasi, dan diksi/pilihan kata. Sama halnya dengan membicarakan perkembangan bahasa Indonesia, tidak dapat dilepaskan dengan pembicaraan mengenai ejaan. Perjalanan ejaan yang pernah berlaku di Indonesia sangat panjang. Dimulai dari ejaan Van Ophuisjhen di tahun 1901 sampai pada ejaan terbaru yakni Pedoman Umum Ejaan Bahasa Indonesia (PUEBI) yang resmi digunakan mulai tahun 2015. Pembicaraan mengenai ejaan juga tidak terlepas dari tokoh-tokoh ahli bahasa maupun pejabat pemerintahan. Nama Van Ophuisjhen diambil sebagai nama ejaan karena beliau yang berjasa membuat aturan-aturan bahasa Melayu. Sementara itu, pada tahun 1947 berlaku ejaan Republik atau yang dikenal 
dengan ejaan Soewandi (yang kala itu menjabat sebagai Menteri Pendidikan). Ejaan terbaru adalah PUEBI yang diresmikan oleh Menteri Pendidikan dan Kebudayaan tahun 2015 yakni Anies Baswdan. Pada materi ini mahasiswa juga mengetahui perjuangan bahwa untuk meneguhkan fungsi bahasa dan membakukan sebuah bahasa bukanlah sebuah proses yang mudah. Untuk itu, dengan materi ini selain mahasiswa dapat menggunakan ejaan yang tepat diharapkan juga mahasiswa mampu menghargai setiap perubahan sehingga tidak semena-mena dalam berbahasa.

Terkait dengan materi Ejaan ini Nuryani telah melakukan penelitian dengan judul Penggunaan Ejaan yang Disempurnakan (EYD) pada Makalah Mahasiswa Non-PBSI. Penelitian ini dilakukan pada mahasiswa di luar Jurusan Pendidikan Bahasa dan Sastra Indonesia di Fakultas Ilmu Tarbiyah dan Keguruan (FITK). Simpulan yang didapatkan berdasarkan penelitian tersebut adalah terdapat bentuk-bentuk kesalahan penggunaan EYD dalam makalah mahasiswa non-PBSI tahun 2011/2012. Beberapa kesalahan yang ditemukan meliputi penggunaan huruf kapital, penggunaan huruf miring, penulisan imbuhan, penggunaan tanda titik, penggunaan tanda koma, dan penggunaan tanda titik dua (Nuryani, 2014b).

Tema yang paling lama dibahas adalah tema mengenai Karangan. Hal itu disebabkan karena banyak sekali cakupan dari materi ini. Materi karangan mencakup penyusunan kalimat efektif, paragraf, etika ilmiah/plagiasi, perencanaan karangan, penalaran, dan notasi ilmiah. Banyaknya unsur yang harus dipelajari sebelum membuat sebuah karangan ilmiah maka materi ini penting untuk disajikan secara runut. Materi mengenai membuat/menyusun kalimat efektif dirasa cukup sulit bagi mahasiswa. Hal tersebut terkait dengan kebiasaan mahasiswa dalam berkomunikasi lisan yang tidak terlalu memperhatikan kaidah atau keefektifan kalimat. Akan tetapi, dengan banyak berlatih mahasiswa akan lebih mudah dalam menyusun kalimat efektif. Meskpiun demikian, tidak menjadi jaminan ketika nanti mahasiswa menyusun karangan ilmiah atau makalah bahkan skripsi mahasiswa akan masih mampu membuat kalimat yang efektif.

Materi menyusun kalimat efektif sangat terkait erat dengan materi paragraf. Menyusun sebuah paragraf bukanlah pekerjaan yang mudah bagi mahasiswa. Akan tetapi, karena menjadi sebuah tuntutan maka mahasiswa berupaya dengan keras untuk melakukan hal tersebut. Setelah mempelajari paragraf dan pengembangannya mahasiswa kemudian diajarkan untuk membuat penalaran. Materi ini penting guna menghindari salah nalar dalam proses pembuatan atau penulisan karya ilmiah. Selain itu, mahasiswa juga diajarkan untuk membuat perencanaan karangan. Karena membuat sebuah karangan ilmiah merupakan sebuah proses yang dirasakan cukup sulit maka dapat dimudahkan dengan cara membuat perencanaannya terlebih dahulu.

Materi yang cukup mendapat perhatian khusus adalah materi mengenai etika ilmiah/plagiasi dan notasi ilmiah. Materi etika ilmiah/plagiasi diberikan guna menghindarkan mahasiswa dari tindakan curang "mencuri" karya orang lain. Sebagai akademisi dan ilmuan, kebersahajaan untuk mengakui sebuah karya yang dikutip dari orang lain adalah mutlak untuk dilakukan. Terlebih bagi mahasiswa PTKI yang notabene sebagai generasi Muslim, maka kejujuran harus sangat dijunjung tinggi. Untuk itulah materi ini mendapat penekanan dan perhatian khusus. Guna menghindari berbagai jenis plagiasi maka diajarkan materi berikutnya, yakni mengenai notasi ilmiah. Materi notasi ilmiah mengajarkan kepada mahasiswa cara mengutip yang benar. Dengan begitu, mahasiswa akan terbiasa menjaga sikap kejujuran dengan selalu manyampaikan bahan atau sumber yang mereka kutip. Selain itu, materi notasi ilmiah juga mengajarkan cara membuat catatan kaki yang benar, dan cara menulis beberapa sumber rujukan baik dalam bentuk catatan tubuh (bodynote) maupun catatan akhir (endnote). Notasi ilmiah juga mengajarkan mahasiswa untuk menulis daftar pustaka dengan benar. Selain cara penulisannya mahasiswa juga mengetahui mengenai fungsi masing-masing catatan di atas dan juga fungsi daftar pustaka. Dengan terlatih berlaku jujur diharapkan nantinya akan 
terbentuk generasi atau ilmuwan Muslim yang selalu berlaku jujur sehingga tidak mengorbankan orang lain.

Materi terakhir dan merupakan kekhasan PTKI adalah Transliterai. Materi ini mengajarkan mahasiswa untuk dapat menyalin huruf atau abjad Arab ke abjad latin. Tujuan dari materi ini adalah mahasiswa mampu menyalin tulisan Arab menjadi tulisan latin sehingga berguna bagi masyarakat umum yang tidak dapat membaca aksara Arab. Materi ini penting mengingat mahasiswa PTKI biasanya menjadi rujukan untuk beberapa hal yang terkait dengan keislaman.

Pada kegiatan pembelajaran untuk materi ini mahasiswa terlibat aktif dan secara langsung mengkaji baik ayat-ayat Al-Quran, Al-hadist, maupun kata-kata mutiara ulama. Selain mengalihaksarakan ayat-ayat yang dikaji mahasiswa juga diajak mengkaji nilainilainya. Dengan begitu pembelajaran yang berlangsung sekaligus dapat mengkaji lebih dalam sehingga nilai-nilai keislaman dapat terinternalisasi dalam diri mahasiswa. Nilai-nilai yang muncul terkait dengan keislaman dapat berupa sikap jujur, nasionalisme, maupun menghargai orang lain.

\section{SIMPULAN}

Simpulan tulisan ini adalah MKWU Bahasa Indonesia memiliki peran yang strategis dalam menumbuhkan sikap jujur, rasa nasionalisme, dan rasa bangga terhadap bahasa dan bangsanya. Hal tersebut dimasukkan secara langsung baik dalam materi, tema kajian, maupun praktik pembelajaran. Untuk itu, mata kuliah Bahasa Indonesia sangat diperlukan oleh mahasiswa baik di perguruan tinggi umum terlebih perguruan tinggi Islam. Hal tersebut dikarenakan perguruan tinggi Islam memiliki tanggung jawab yang lebih berat mengingat menyandang nama Islam. Selain itu, terkait juga dengan visi yang dikembangkan oleh UIN Syarif Hidayatullah Jakarta yang juga dimasukkan ke dalam tagihan-tagihan tulisan maupun keterampilan berbicara mahasiswa. Adapun visi UIN Syarif Hidayatullah Jakarta adalah keislaman, keindonesiaan, dan salah satu upayanya adalah mendekatkan mahasiswa perguruan tinggi Islam dengan bahasanya sendiri. Selain itu, MKWU Bahasa Indonesia akan dapat berperan secara optimal dalam menanamkan rasa cinta tanah air dan memperkuat rasa nasionalisme jika diikuti dengan pelaksanaan pembelajaran di kelas secara baik oleh pengampunya.

\section{DAFTAR PUSTAKA}

Alwi, H. (2011). Butir-butir Perencanaan Bahasa. Jakarta: Badan Pengembangan dan Pembinaan Bahasa, Kemendikbud.

Arifin, E. Z., \& Tasai, S. A. (2015). Bahasa Indonesia sebagai Mata Kuliah Pengembangan Kepribadian. Tangerang: Pustaka Mandiri.

Bahtiar, A., \& Fatimah. (2014). Bahasa Indonesia untuk Perguruan Tinggi. Jakarta: In Media.

Direktorat Jenderal Pembelajaran dan Kemahasiswaan, K. R., Teknologi, dan Pendidikan Tinggi. (2016). Buku Ajar Mata Kuliah Wajib Umum Bahasa Indonesia: Ekspresi Diri dan Akademik. Jakarta: Kemenristek Dikti.

Gani, R. A., \& Fitriyah, M. Z. A. (2010). Disiplin Berbahasa Indonesia. Jakarta: FITK Press. Ikhwan, A. (2016). Perguruan Tinggi Islam dan Integrasi Keilmuan Islam. At-Tajdid: Jurnal Ilmu Tarbiyah, 5(2), 159-187.

Kuntarto, E. (2016). Rancang Bangun Model General Education melalui Penguatan Pendidikan Karakter pada MKWU Bahasa Indonesia di Perguruan Tinggi. Paper presented at the Prosiding Seminar Nasional Bahasa, sastra, dan Pengajarannya V. 
Kusnadi, H. (2016). Peranan Mata Kuliah Wajib Umum (MKWU) terhadap Pengembangan Karakter Mahasiswa Pendidikan Ekonomi Angkatan 2015 di Fakultas Ekonomi Universitas Negeri Gorontalo Universitas Negeri Gorontalo Gorontalo

Mulyana, A. T. (2018). Model Pengembangan Bahan Ajar Bahasa Indonesia sebagai Mata Kuliah Wajib Umum (MKWU) Berbasis Paradigma Pembelajaran Abad Ke-21 pada Aspek Career and Life Skills (CLS). Jurnal Inovasi Pendidikan MH Thamrin, 2(2), 4354.

Nata, A. (2017). Bangunan Epistimologi Pendidikan Islam. In J. Musfah \& Y. Herlanti (Eds.), Pendidikan Islam: Isu dan Inovasi. Jakarta: FITK Press.

Nuryani. (2014a). Penggunaan Ejaan yang Disempurnakan (EYD) pada Makalah Mahasiswa Non-PBSI. Paper presented at the Prosiding Seminar Internasional Jurusan Pendidikan Bahasa dan Sastra Indonesia 4-6 November 2014, UIN Syarif Hidayatullah Jakarta.

Nuryani. (2014b). Sikap Bahasa Masyarakat Urban terhadap Bahasa Indonesia (Menemukan Tipe Pembelajaran Bahasa Indonesia di Sekolah Wilayah Rural dan Urban). Paper presented at the Prosiding Konferensi Internasional Fakultas Ilmu Budaya Universitas Airlangga Surabaya, Surabaya.

Putra, D. A. K. (2015). Keterampilan Membaca Kritis pada Mahasiswa Jjurusan Perbankan Syariah Semester IV Fakultas Syariah dan Hukum, UIN Syarif Hidayatullah Jakarta. Dialektika: Jurnal Bahasa, Sastra, dan Pendidikan Bahasa dan Sastra Indonesia, 2(1), 77-88.

Rahardi, K. (2010). Bahasa Indonesia untuk Perguruan Tinggi. Jakarta: Penerbit Erlangga.

Risetdikti, D. B. (2017). Bahan Ajar Mata Kuliah Wajib Umum. from http://belmawa.ristekdikti.go.id/2016/12/09/surat-edaran-bahan-ajar-mata-kuliahwajib-umum/

Simarmata, H. T. (2017). Indonesia Zamrud Toleransi. Jakarta: PSKIK-Indonesia.

Tasai, A., \& Arifin, E. Z. (2010). Cermat Berbahasa Indonesia untuk Perguruan Tinggi. Jakarta: Akademika Pressindo.

Walid, M. (2011). Model Penddidikan Karakter di Perguruan Tinggi Agama Islam (Studi tentang Pendidikan Karakter Berbasis Ulul albab di Universitas Islam Negeri Maulana Malik Ibrahim Malang). El-Qudwah, 1(5), 115-156.

Widjono, H. (2012). Bahasa Indonesia: Mata Kuliah Pengembangan Kepribadian di Perguruan Tinggi. Jakarta: Grasindo. 